Available online at: http://proceeding.rsfpress.com/index.php/pss/index

LPPM UPN “Veteran” Yogyakarta Conference Series

Proceeding on Political and Social Science Series (PSS)

Volume 1 Number 1 (2020): 9-16

\title{
Globalization And Locality: Global Communication And Digital Revolution In The Borderless World Era
}

\author{
Ariesani Hermawanto, Melaty Anggraini \\ Universitas Pembangunan Nasional Veteran Yogyakarta. Indonesia \\ E-mail address ariesani.hermawanto@upnyk.ac.id,E-mail address \\ Melaty.anggraini@upnyk.ac.id
}

\begin{abstract}
Globalization is a phenomenon after the Cold War and continues in the era of the new millennium. It also has a direct impact on the community at the local level. The citizens' activities are easier because everyone can always be connected through the global information network. The approach used is related to the concept of glocalization, which means a global process which is then adapted by local.This paper focuses on the link between globalization and locality in an era of a world without borders. The findings in this paper is the paradox impacts from the reciprocal reaction between global processes and local due to the development of communication and the digital revolution that have beneficial and unfavorable impacts.
\end{abstract}

Keywords : Globalization, Digital Revolution, Borderless world

\section{INTRODUCTION}

This is an open access article under the CC-BY-NC license.

Globalization is an important phenomenon in the modern era. The term globalization originally appeared around the 1960s, which is widely used in popular and academic writings that describe a process, condition, system, or also a force and dynamics of age. Globalization, as a concept, refers to the increasing awareness of the world as a whole. This term is often used to describe changes in world society and is influenced by communication, cultural exchange, and cross-border trade. Globalization is an interconnected world and marked by the existence of global mass culture. The general term of globalization shows a world condition where there are close interconnections of social, political, economic, cultural, environmental, communication, and so on. These have caused the boundaries of one formal area to be irrelevant, or in other words, does not hinder the process of further development of this globalization process. 
The characteristics of globalization create a new social network and increasingly more complex. This illustrates the continuing expansion and flexibility of social relations in a world society in its activities and interdependence with one another. Globalization also involves intensifying social exchanges and social activities at the local level. This is characterized by the internet network that spreads widely throughout the world, where much information can be sent in a short time. This is also supported by digital developments that provide information on ongoing events in real-time, even though the distance is far. In other words, according to Anthony Giddens, globalization can be explained as the intensification of social relations in the sphere of the world, which connects the distance of separate localities. Local transformation, as part of globalization, is the expansion of social connection beyond time and space.(Giddens, 1991)

The expansion and intensification of social interconnection and the interdependence of society have resulted in human consciousness regarding the importance of mutual adjustments in social interactions with one another, where geographical boundaries no longer limit communication between communities (borderless world). This gradually transforms individuals and societies towards a collective identity in an increasingly globalized international world. According to Steger, globalization is a multidimensional social process that creates and intensifies interdependencies and exchanges at the world level and, at the same time, fosters public awareness of the deep relationships between local and the far.(Stegger, 2003)

The relations between the global and local dimensions are known as glocalization. This concept, according to Roland Robertson, refers to a phenomenon that spreads, flows, and also is scattered from one place to another and are adapted to the local level.(Robertson, 2014) This also applies to communications that occur at the local community level through assistive devices such as cell phones and also through social media, which is not only verbally spoken directly but also through a short message or text media, sharing images and symbols that are interpreted as a form emojis in having a conversation. It can be said that the changes in communications at the local dimension are strongly influenced by the development of internet networks. The people can make many social interactions more virtually through a medium than directly.

The revolution of communication also occurs because the human needs who always want something that can make their life easier, so that a sophisticated tool or technology is created to make it easier to communicate. To understand the revolution of communication that is currently happening, it is closely related to several things, such as the connection with the era of globalization, which makes the world community more interconnected and interdependent, more make community interaction openly, and also the development of the digitalization era. Furthermore, it will discuss what matters influence the dynamics of global communication in detail and the impact of social changes due to the digital revolution. 


\section{REASEARCH METHODOLOGY}

The method used in this study is descriptive qualitative. In qualitative research, it is descriptive-analytic. The data obtained, such as the results of observations, interviews, documentation results, document analysis, and field survey results notes. This writing will focus on scientific writings on globalization and locality to analyze social problems that occur in the globalization era in the local community. Sources can be from state documents, textbooks, scientific journals, and several interviews with related sources. The sources are divided into two parts, namely; primary sources and secondary sources. Primary sources can be obtained from individuals, focus groups, and a group of respondents. Meanwhile, secondary sources can be obtained from comments, interpretations, or discussions on the subject matter to be studied.

\section{III.LITERATURE REVIEW}

Globalization is widely interpreted as a value-free form so that globalization is not tied to a particular discourse and free to be used to see the changes in the world. Globalization has multidimensional aspects of economic, political, social, and cultural. Globalization also means a lot of changes, followed by the development of technology and information. As a result of these changes, it creates new problems that lead to the field of human security. Social ethics is needed in dealing with the development of globalization. There are several kinds of literature which, according to the author, can help understand the meaning of globalization and its impacts.

The first literature from the work of Anthony Giddens (1991) entitled "The Consequences of Modernity," in this book explains how the views of various experts about the emergence of modernity and many sparked various controversial views due to the emergence of the era of modernity. Here Giddens leads his readers to understand that the era of modernity is marked by the emergence of negative sides in the social system of society such as capitalism, social strata, and other negative views by the social community. It had led people to understand what is a social system that may have existed before but was not realized by society and formed a more administrative social system with its emergence of a corporate institution. In conclusion, as explained in this book, the era of modernity did not appear in a new form but was a refinement of the pre-modernity era, which was formed by the social, cultural values of society as well as the emergence of globalization. The negative side of the era of modernity or globalization can be overcome by studying sociological relationships in society and by learning the previous social values that were formed in society. These social values will also filter out the negative impacts that arise along with the entry of the modernity era.

In Peter Singer's (2002) work entitled "One World," it is also explained what the meaning of globalization and how it is necessary to understand the concept of globalization; and also the dangers of its emergence. The globalization continues to develop nation-states so as to disguise boundaries and create short-cut initiatives to understand the world. Singer sees that the progress of globalization, which has resulted in many new discoveries in the fields of 
knowledge, technology, ideology, and the corporate sector is not only looking for a solution to problems. It raises any new problems which are unwittingly used as guidelines for values that are commonly carried out in the structure of social society in the era of globalization.

Finally, the literature study on "Local and Global: The Management of Cities in The Information Age" by Jordi Borja and Manuel Castells (1997). In the discussion of globalization, it is more emphasis on city information and management, the impact of globalization on urban spatial planning, and social structure. This literature also explained the impact of the development of globalization by taking the point of view of the gender discrimination of women, children, and certain ethnicities, which became the basis for social scientists to explain the creative and destructive processes of globalization.

\section{III.1. Global Communication Dynamics}

Communication is the main requirement in social interaction, namely as a conveyor of information to other parties. The development of communication technology in this globalization era has an impact on changing the way of communicating in a society. Currently, communication is not only limited to a conversation between two individuals face to face but transforms into a complex communication process that can penetrate the boundaries of space, time, number, capacity, and speed. In communicating activities, feedback is needed as a form of communication pattern reaction because it is a way for someone to get what they want. Therefore, we need the ability to build a good and clear communication supported by the participation of communication media.

The way of communicating activities underwent a significant and rapid transformation due to the presence of communication technology, which was later referred to as the communication revolution. These were marked by rapid changes and driven by various discoveries in technologies of information. Something that previously impossible is possible now due to technological advances that offer a wide variety of information and communication sources and remove barriers to communication

\section{III.2. Digital Revolution}

The concept of the digital revolution has evolved since the invention of computers and the Internet at the beginning of the Industrial Revolution 3.0 in the 1960s by the discoveries of semiconductors and the spread of computers and the Internet among the people. The digital revolution can play a role in changing society in a positive direction. (Collinsdictionary) They led to a wave of revolution in the field of information towards a digital form. In this revolutionary wave, it has changed people's lives in communicating activities and created a "Network Society" because many things are done virtually via the Internet and online. (Igi Global) The development of the digital revolution helps economic growth, education, and democratic process due to the emergence of information superhighways resulting in a new world information order. It makes people easier to obtain information and conduct business transactions through a communication tool without boundaries. However, the development of the early digital revolution in the Revolution 3.0 era is still considered by the community 
to raise social problems such as cultural gaps in people's lifestyles for the development of digital electronic technology. The improvements are needed to solve these problems, and further has formed social innovations better. The Industrial Revolution 4.0 continues the form of the digital revolution that was born and developed at the time of the Revolution 3.0, but with a breakthrough in the digital realm that more complete than before. This does not only create technology that beneficial to the development and progress of the community's economy but also able to resolve social issues that previously resulted in gaps in society due to technology and anticipate the emergence of cyber societies.

The development of the telecommunications industry ushered in an era of digital transformation where many fields began to be connected in the internet network. The shift of investment in the telecommunications industry has resulted in a variety of technologies and has sustained major shifts in the exchange of information flows and capital in view of the global economy.

\section{III.3. Information Flow and Its Impacts}

The existence of technology gave birth to new media and social media that have eliminated the boundaries of space, time, and the depth of social patterns. This also raises the globalization of information, which without realizing the presence of this technology, makes a new social system towards digital intimacy. The conventional pattern of relationships in the social community system, which is usually carried out through direct interaction, has begun to become alienated with the frequency of digital interactions, which has led to the term "virtual society(Britannica)

The development of technology and information raises two sides, namely, positive and negative. The positive side is such as facilitating diplomacy in general, such as representation, promotion, reporting, negotiation, which usually has to be done face-to-face, and light correspondence can be practically done virtually and relatively efficiently. There are many advantages and benefits of digital technology development, such as spurring people's economic growth through digital economic activities based on the sharing economy concept. Even so, there is a negative side that emerges where the development of digital technology also has the opposite effect, namely the effect from the security aspect, the formation of a virtual society creates a cyber society such as the emergence of hackers who can break into state or company information, online fraud, propaganda through social media, even acts of terrorism virtually. For this reason, people need to be more selective and critical in utilizing the information provided in the development of communication technology and information.

The rapid development of technology and the flow of information is a challenge for the world community. The existence of technological developments has provided benefits and benefits to the world community, but in other parts, it is necessary to prepare human resources who can survive and develop in the climate of globalization. Globalization marks changes in the acceptance of information flow that is taking place rapidly in various parts of the world; even these flows can have a domino effect on one country to another. 


\section{III.4. Interconnection and Interconnection of the World Community}

Interconnection and interdependence are related to the emergence of the globalization phenomenon in the international world. Globalization becomes the starting point of the connection of the world community. Globalization shows an integration process that involves expanding and deepening the interdependence between people and countries around the world, which then produces what is called global citizenship. The national boundaries of the nation-state are not considered so important, and the old way of understanding about state sovereignty has shifted. The concept of individuals in a region can also be seen in a global context.

The existence of a digital revolution is making every society, even countries, connected very quickly so that there is no more difficulty communicating with other people and countries. In the past, people were still connected conventionally in communicating and making transactions to fulfill their needs, which took a relatively long time and was inefficient. The existence of the digital revolution allows people to connect quickly and able to increase their business activities and innovative services, thus encouraging increased success in the global economy. This is real support from advances in facilities and infrastructure, such as transportation and information technology. This process has increased the interconnectedness and interdependence of individuals and countries, as well as having a greater impact on the environment, economy, culture, political system, and lifestyle of the world community.

\section{III.5. Borderless Society and World}

The high development of the technology of information and communication causes the world to shrink, and states lose their national borders as Ohmae (2005) said that national borders are far less constrictive than they once were. The world is an increasingly borderless place. (Ohmae, 2005) All countries can always be connected to one another and know the developments in other countries transparently. The Internet dominantly forms new globalization, which reduces the authority and relevance of national governments. (Goldsmith and $\mathrm{Wu}, 2006$ )This occurs due to the existence of the Internet and social media such as Facebook, Twitter, Instagram, and YouTube channels and carries out all economic transactions easier. The community of communication patterns changes into new forms that are always connected to the network or "Network Society." People are becoming smarter and not disrupted by technological sophistication if they can use it properly and wisely. The scope of society is increasingly unlimited due to developments in digital technology.

The wider area of information exchanges helps all human activities without being limited by space and time by the internet network system. This era is known as the era of the third world, or cyberspace, a world where all the activities of the people are supported by the internet network system and easily accept the development of technology and information 
as a global culture. With the acceptance of this global culture, the rapid development of technology and society is increasingly active in using the Internet.

One of the important things when people get a lot of technological conveniences, in other parts it causes laziness, addiction, and a reduced sense of social empathy due to reduced ability to interact with the environment in the real world. The almost limitless freedom in cyberspace also makes it difficult to control the spread of information. The rise of crimes in the cyber world, known as cyber-crime, causes almost nothing to guarantee data security in cyberspace. This borderless cyber world also gave birth to a generation group that differentiates it from people who are not familiar with the existence of the Internet, which is commonly referred to as i-Generation (Internet Generation).

\section{CONCLUSION}

The finding of this paper emphasizes the paradox of the impacts of globalization at the local level, which are caused by the strong development of digital technology, which is very fast and massive. On the one side, the development of digital technology has increased interactions at global and local levels and has brought worlds that separated by distance and time closer together. But at the same time, it becomes a paradox because on the other side at the local level- it has the potential influences to break social ties and individual relationships that exist in the same local environment.

The era of globalization, accompanied by information and communication technology innovations, has an impact on the global changes in the world. The world becomes borderless with people's interactions in cyberspace actively. The existence of social media has become an important phenomenon that allows its users to express their opinions openly. Communication activities using the internet network system, on the other hand, gave birth to a generation of people who experience dependence on internet access and information technology, which has also eliminated social boundaries in people's lives. This allows for a social gap in taking advantage of technological developments in the digital era. Therefore, society in accepting the trend of digitalization as a global culture must be more careful in order to avoid the negative impact of technology that has been made by themselves.

\section{REFERENCES}

\section{Books:}

Borja, Jordi \& Castells, Manuel. 1997. Local and Global: The Management of Cities in the Information Age, London: Routledge.

Giddens, Anthony.1991. The Consequences of Modernity.United Kingdom: Stanford University Press.

Goldsmith, Jack \& Tim Wu. 2006. Who controls the Internet?: illusions of a borderless world, New York: Oxford University Press, p vii. 
Ohmae, Kenichi. 2005. The Next Global StageChallenges and opportunities in Our Borderless World, New Jersey: Wharton School Publishing.

Robertson, Roland. 2014. Europe in A Global Context: European Glocalization in Global Context, New York: Palgrave McMillan.

Singer P.2002. One World: The Ethics of Globalization, London: Yale University Press. Steger, Manfred B.2003.Globalization: A Very Short Introduction, New York: Oxford University Press.

\section{Internet :}

https://www.collinsdictionary.com/dictionary/english/digital-revolution, accessed on 25 September 2020.

https://www.igi-global.com/dictionary/network-society/20182, accessed on 25 September 2020

https://www.britannica.com/topic/virtual-community, accessed on 25 September 2020 